\title{
Uma aluna da EJA atuando como bolsista de IC Júnior: relato de uma experiência
}

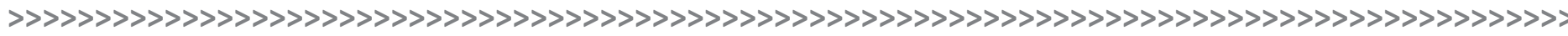

Odete de Oliveira Bernardo* Daiane Martins Bocasanta*

No último semestre de 2017, iniciei como bolsista de Iniciação Científica Jr. no Colégio de Aplicação, sob a orientação da professora Daiane Martins Bocasanta. O objetivo da pesquisa da qual participei era identificar e analisar como estudantes da Educação de Jovens e Adultos (EJA) são posicionados como sujeitos em livros didáticos voltados para a Alfabetização e Pós-Alfabetização em relação ao que consideramos conhecimentos tecnocientíficos.

No início, fiquei entusiasmada em saber que iria fazer minha primeira pesquisa, mas também tive um certo medo, receio de não conseguir ir adiante. No entanto, a professora Daiane me deu todo o suporte e apoio. Logo no início da investigação, antes de ir para aula, eu pegava alguns livros didáticos e levava para casa. Todos os dias eu fazia uma leitura inicial, folha por folha, fazendo algumas marcações no caderno e tirava algumas fotos daquilo que achava importante para a pesquisa. A cada quinze dias, eu me encontrava com a professora Daiane para acompanhar o andamento do trabalho. Ela sempre me elogiava, dizendo que estava muito bom, que podia continuar, mas eu ficava preocupada, querendo saber se realmente estava fazendo meu trabalho direito. Por ser aluna da EJA, eu achava que sabia muito pouco, pois tinha parado de estudar há anos. Não sou mais jovem, mas pensava: "eu fui escolhida e tenho que tentar fazer o meu melhor".

A cada dia que passava ia aprendendo mais, e assim fui me envolvendo muito com a pesquisa, pois ela tinha um pouco a ver comigo, afinal, eu sou aluna da EJA e pesquisava sobre como os alunos são descritos em livros voltados para o ensino na EJA. Essa pesquisa durou um ano. Com a ajuda da professora, escrevi um resumo que foi submetido ao Salão UFRGS Jovem. Nosso resumo ficou assim:

\section{Os alunos da EJA e os conhecimentos tecnocientíficos: uma análise de livros didáticos}

Este trabalho tem como objetivo identificar e analisar como estudantes da Educação de Jovens e Adultos (EJA) são posicionados em livros didáticos voltados para a alfabetização de pós-alfabetização $\left(1 .^{\circ}\right.$ ao $5 .^{\circ}$ ano do Ensino Fundamental) em relação ao que consideramos conhecimentos tecnocientíficos. Esse estudo justifica-se pela presença cada vez mais marcante da tecnociência na vida de todas as pessoas. Os avanços tecnocientíficos, ao mesmo tempo em que trazem benefícios, também podem trazer transtornos e mais desigualdades. A tecnociência é um conceito utilizado para designar mais do que apenas e integração ou fusão entre ciência e tecnologia. Tecnociência, nesse estudo, é entendida como um entrelaçamento entre questões relativas a produção do

* > Aluna da Educação de Jovens e Adultos do Colégio de Aplicação da Universidade Federal do Rio Grande do Sul. Pesquisadora de Iniciação Científica. E-mail: odete. obernardo55@gmail.com

** > Pedagoga, Mestre em Educação e Doutora em Educação pela Universidade do Vale do Rio dos Sinos. Professora dos Anos Iniciais do Departamento de Humanidades do Colégio de Aplicação da UFRGS. E-mail: daianebocasanta@gmail.com 
conhecimento científico, técnicas e nosso modo de vida atual. O material de pesquisa examinado é composto por um conjunto de livros didáticos voltados para os anos iniciais da EJA: Coleção Alcance EJA (volumes 1, 2 e 3) e Coleção É Bom Aprender (volumes 1, 2 e 3). A metodologia de pesquisa utilizada baseiase em analisar o que havia nos livros sobre ciência e tecnologia. Foi realizada uma leitura inicial, fazendo marcações e anotações em um caderno. Após, registrou-se em fotografia as imagens que mais chamaram a atenção. Feito isso, deu-se o processo de identificação do que era recorrente nesses materiais. Os resultados da pesquisam indicam: a) os livros apontam para a necessidade de todos, independente da idade ou do contexto social, entrarem no jogo da tecnociência. Assim, todos precisam dominar o uso das tecnologias como condição para ter uma vida melhor e melhores oportunidades; b) nos livros, em algumas situações em que pessoas idosas aparecem usando o computador, é enfatizado o sucesso dessas pessoas e o quanto esse aprendizado mudou suas vidas; e c) os livros nos mostram o jovem como quem ensina o idoso e como quem sabe mais sobre tecnociência. Os livros nos remetem ao entendimento de que o idoso não consegue aprender com tanta facilidade quanto o jovem. Em conclusão, foi possível evidenciar que num mundo de oportunidades desiguais, em que nem todos têm acesso aos conhecimentos tecnocientíficos, computadores, smartphones, internet, etc., esses livros posicionam os sujeitos estudantes da EJA, especialmente os adultos e idosos, em uma posição retardatária na busca e aquisição do conhecimento tecnocientífico.

\section{Palavras-chave:}

Educação de Jovens e Adultos; Livro didático; Tecnociência.

Quando chegou o grande dia da apresentação, senti um pânico: “Meu Deus!”. Mas era preciso lembrar do que a professora sempre falou: "Fica tranquila, vai dar tudo certo, tu sabes que eu estou aqui para te ajudar sempre que precisar”. Assim, montei o banner e uma apostila. Quando eu vi tudo pronto e mostrei para a professora, ela ficou encantada e disse que sabia que eu ia conseguir.

Na hora da apresentação, estava nervosa, ansiosa e preocupada porque eu seria a aluna mais velha no meio de tantos jovens. No final, deu tudo certo. A apresentação foi um sucesso. Fui elogiada tanto pela orientadora quanto pelos avaliadores do evento. Horas depois, a professora Daiane me mandou uma mensagem dizendo que eu havia recebido destaque no Salão. Eu praticamente surtei! Era muita emoção! Não imaginava que meu trabalho seria escolhido entre os de tantos jovens. No dia da entrega do troféu de destaque, fui acompanhada com minha orientadora. Subir ao palco para receber o prêmio de destaque foi uma emoção muito grande, pois estava representando a modalidade de Educação de Jovens e Adultos (EJA) num salão cujo próprio nome diz que é para jovens. Para completar, minha filha Pâmela, aluna do curso de publicidade e propaganda da UFRGS, também foi destaque no Salão de Ensino da UFRGS e recebeu o troféu por uma pesquisa que fez baseada na minha trajetória como aluna da EJA. Em seu estudo, ela criou um site que funciona como um auxílio para facilitar o uso de artefatos digitais para alunos da EJA. Fomos até entrevistadas pelo Jornal da UFRGS! Foi uma experiência maravilhosa pois vi que tenho capacidade e que, aos 50 anos, tenho as mesmas condições de aprender e produzir que os jovens, e pretendo continuar estudando e pesquisando. 